\title{
ANALISIS BEBAN KERJA TERHADAP KEBUTUHAN PEGAWAI ADMINISTRASI DALAM MENJAMIN OPTIMALISASI OPERASIONAL AKADEMIK
}

\author{
Yusuf \\ Anfas \\ Raden Sudarwo \\ Universitas Terbuka \\ e-Mail: yusuf_se@ut.ac.id
}

\begin{abstract}
The number of employees needs to be based on the workload of administrative staff UPBJJUT Ternate. To calculate the activity time employees who used to work and time are not, researchers using work sampling table. Methods of calculating labor requirements are based on the calculation of the workload with the approach per duties of office according MenPAN No. KEP/75/M.PAN/7/2004 on Guidelines for Employee Needs Calculation based Workload in the framework of preparation of formation of civil servants. Samples were UPBJJ-UT Ternate employee status with the principal administrative officer jobs based Target Achievement Quality Employees (CSKP). Calculation and data processing using Microsoft Excel. The study concluded that there is a significant result in the use of working time and to have the results of the number of employees needed for the actual number of employees, it is known that there are 7 functions of employees, unit administrative KTU has an excess number of employees as much as 1 employee and BPP has a shortage of employees as many as 1 employee. For registration and testing PDA unit has a shortage of the number of employees as much as 1 employee.
\end{abstract}

Keywords: employee quality target achievement, work sampling, workload.

\begin{abstract}
ABSTRAK
Jumlah kebutuhan pegawai harus didasarkan kepada beban kerja pegawai administrasi UPBJJ-UT Ternate. Untuk menghitung waktu aktifitas pegawai yang digunakan untuk bekerja dan waktu yang tidak, peneliti menggunakan tabel work sampling. Metode perhitungan kebutuhan tenaga kerja didasarkan pada perhitungan beban kerja dengan pendekatan per tugas jabatan sesuai Keputusan MenPAN Nomor: KEP/75/M.PAN/7/2004 tentang Pedoman Perhitungan Kebutuhan Pegawai berdasarkan Beban Kerja dalam rangka Penyusunan Formasi PNS. Sampel penelitian adalah pegawai UPBJJ-UT Ternate berstatus pegawai administrasi dengan pokok pekerjaan didasarkan Capaian Sasaran Kualitas Pegawai (CSKP). Perhitungan dan pengolahan data menggunakan Microsoft Excel. Penelitian ini menyimpulkan bahwa terdapat hasil yang signifikan pada penggunaan waktu kerja dan memiliki hasil jumlah karyawan yang dibutuhkan terhadap jumlah aktual karyawan, dapat diketahui bahwa terdapat 7 fungsi karyawan, unit tata usaha KTU memiliki kelebihan jumlah karyawan sebanyak 1 orang karyawan dan BPP memiliki kekurangan jumlah karyawan sebanyak 1 orang karyawan. Untuk unit registrasi dan pengujian PDA memiliki kekurangan jumlah karyawan sebanyak 1 orang karyawan.
\end{abstract}

Kata kunci: beban kerja, capaian sasaran kualitas pegawai, work sampling. 
Setiap organisasi baik yang berbentuk perusahaan ataupun institusi, baik yang bersifat profit maupun non-profit (nirlaba) saat ini dihadapkan pada iklim globalisasi yang mengarah pada peningkatan pembangunan terutama yang bertujuan untuk menciptakan kesejahteraan bangsa. KEPMEN DIKNAS RI Nomor 107/U/2001 tentang penyelenggaraan Program Pendidikan Tinggi Terbuka Jarak Jauh (PTJJ) juga membuka peluang bagi perguruan tinggi lain untuk berpartisipasi dalam penyelenggaraan pendidikan tinggi jarak jauh di tanah air. Merupakan fenomena yang menggembirakan, meskipun harus disadari bahwa penyelenggaraan pendidikan tinggi jarak jauh mensyaratkan kualitas dan kuantitas.

Universitas Terbuka mendayagunakan seluruh keuntungan yang diperoleh dari usaha bisnisnya untuk kepentingan meningkatkan kualitas pendidikan. Penyelenggaraan pendidikan di UT dalam rangka pencapaian tujuannya menghasilkan lulusan yang berkualitas juga tidak terlepas dari peran serta tenaga pendidik dan tenaga penunjang lainnya. Upaya UT untuk menghadapi tuntutan pembangunan dapat dilakukan melalui pengelolaan organisasi yang efektif dan efisien. Usaha yang efektif dan efisien mengandung arti bahwa output dari setiap pegawai memenuhi apa yang ditargetkan organisasi.

Dengan jumlah hasil kerja yang mampu dihasilkan setiap pegawai maka dapat diketahui berapa tingkat kebutuhan pegawai untuk mencapai target. Hal tersebut dapat dilakukan melalui metode pengukuran beban kerja, sehingga pegawai dapat bekerja optimal sesuai batas kemampuannya. Beban kerja seseorang sudah ditentukan dalam bentuk standar kerja perusahaan menurut jenis pekerjaannya (Mangkuprawira, 2003). Beban kerja yang dibebankan kepada pegawai dapat terjadi dalam tiga kondisi. Pertama, beban kerja sesuai standar. Kedua, beban kerja yang terlalu tinggi (over capacity). Ketiga, beban kerja yang terlalu rendah (under capacity). Beban kerja yang terlalu tinggi atau rendah akan berdampak terjadinya inefisiensi kerja.

Persaingan yang tinggi menuntut adanya perbaikan di lingkup kerja organisasi seperti pengurangan biaya (efisiensi), peningkatan produktifitas karyawan dan melakukan segala sesuatu dengan lebih baik dan murah. Hal tersebut tidak terlepas dari peranan SDM perusahaan. Peranan SDM dalam hal ini adalah sebagai penggerak utama dalam membantu perusahaan mencapai visi, misi dan tujuan serta strateginya.

Perencanaan tenaga kerja yang baik adalah hal yang penting untuk dilakukan yaitu meliputi analisis pekerjaan dan beban kerja perusahaan secara keseluruhan. Menurut Moekijat (2008), analisis beban kerja merupakan metode yang biasa digunakan untuk menentukan jumlah atau kuantitas tenaga kerja yang diperlukan. Beban kerja yang didistribusikan secara tidak merata dapat mengakibatkan ketidaknyamanan suasana kerja karena pegawai merasa beban kerja yang dilakukannya terlalu berlebihan atau bahkan kurang. Sumber Daya Manusia pada masing-masing unit harus direncanakan dan dikelola dengan baik agar beban kerja yang ditanggung oleh masingmasing pegawai sesuai dengan kapasitas yang dimiliki. Jika terjadi kelebihan beban kerja, maka para karyawan akan merasa kelelahan dalam melayani kebutuhan administrasi mahasiswa dan dapat berakibat menurunnya kinerja layanan.

SDM administrasi UPBJJ-UT Ternate pada penelitian ini terdiri dari Kasubag Tata Usaha (KTU), staf administrasi umum (ADU), Bendahara Pembantu Pengeluaran (BPP), staf Pengadministrasian Keuangan (ADK), staf Teknisi Sarana dan Prasarana Kantor (TSP). SDM tersebut berada pada unit tata usaha. Kemudian Koordinator Registrasi dan Ujian (KRU) dan staf Pengumpul dan Pengelola Data Akademik (PDA). SDM tersebut berada pada unit registrasi dan pengujian. Jumlah SDM administrasi pada tiap UPBJJ berbeda-beda tergantung pada jumlah mahasiswa yang dikelola serta penggunan anggaran belanja pegawai. Masing-masing UPBJJ 
mendapatkan job description yang sama tanpa ada perbedaan. Pengukuran beban kerja perlu dilakukan kembali untuk mengetahui jumlah kebutuhan pegawai secara optimal.

UPBJJ-UT Ternate memiliki amanat mulia yaitu meningkatkan kualitas SDM di Provinsi Maluku Utara. Untuk mendukungnya, optimalisasi organisasi harus diwujudkan. Hal ini dikarenakan ketidakefisienan akan menyebabkan turunnya produktivitas organisasi dan mengancam pelaksanaan pencapaian tujuan mulia UT. Hal inilah yang kemudian melatarbelakangi pentingnya melakukan analisis beban kerja dan jumlah kebutuhan karyawan di lingkungan kerja UPBJJ-UT Ternate.

Populasi penelitian yaitu pegawai administrasi akademik dan kemahasiswaan pada unit tata usaha dan unit registrasi dan pengujian UPBJJ-UT Ternate dengan jumlah populasi sebanyak 7 orang responden. Adapun cara pengambilan sampel masing-masing unit dilakukan dengan purposive sampling. Pengumpulan data primer mengenai karyawan diperoleh melalui metode work sampling yaitu pengamatan terhadap aktifitas pokok atau tugas pokok selama jam kerja dengan jarak waktu pengamatan setiap 10 menit. Pengamatan dilakukan selama 8.5 jam waktu kerja selama dua hari sehingga diperlukan 14 hari untuk melakukan pengamatan untuk 7 responden.

Aktifitas yang diamati dalam penelitian menggunakan tabel work sampling dikelompokkan menurut kategori kegiatan produktif, tidak produktif, dan pribadi. Menurut llyas (2004), pengelompokkan kegiatan dapat disesuaikan dengan tujuan dan kebutuhan penelitian. Kegiatan produktif merupakan semua kegiatan yang berhubungan dengan penyelesaian pekerjaan seperti yang terdapat pada uraian tugas-tugas pokok. Kegiatan tidak produktif meliputi kegiatan yang dilakukan karyawan yang tidak bermanfaat bagi pekerjaan seperti terlambat, bermalas-malasan, mengobrol, dan sebagainya. Kegiatan pribadi merupakan kegiatan yang dilakukan karyawan untuk menghilangkan kelelahan.

Pengumpulan data primer berupa standar kemampuan rata-rata waktu penyelesaian dan kuantitas beban tugas-tugas pokok pekerjaan selama setahun dilakukan dengan metode gabungan wawancara dan observasi. Adapun data sekunder dikumpulkan melalui studi kepustakaan.

Tabel 1. Format Tabel Work Sampling.

Bagian :

Tanggal:

Tempat :

\begin{tabular}{|c|c|c|c|c|}
\hline \multirow{2}{*}{ Waktu } & \multicolumn{4}{|c|}{ Kegiatan yang dilakukan pegawai } \\
\hline & Produktif & Tidak Produktif & Pribadi & Ket. \\
\hline \multicolumn{5}{|l|}{ 08:00 } \\
\hline \multicolumn{5}{|l|}{ 08:10 } \\
\hline \multicolumn{5}{|l|}{$08: 20$} \\
\hline ..dst... & & & & \\
\hline
\end{tabular}

Frekuensi dan waktu untuk menyelesaikan aktifitas mencerminkan nilai beban kerja yang selanjutnya digunakan untuk menentukan jumlah kebutuhan tenaga kerja melalui analisis perhitungan kebutuhan tenaga kerja. Jumlah tenaga kerja yang dibutuhkan kemudian dapat dibandingkan dengan jumlah tenaga kerja riil. 
Tabel 2. Operasionalisasi Variabel.

\begin{tabular}{llll}
\hline \multicolumn{1}{c}{ Variabel } & \multicolumn{1}{c}{ Definisi Operasional } & \multicolumn{1}{c}{ Indikator Penilaian } & \multicolumn{1}{c}{ Sumber } \\
\hline Beban & sekumpulan atau sejumlah kegiatan & 1. Frekuensi pekerjaan & Suharyono dan \\
kerja & $\begin{array}{l}\text { yang harus diselesaikan oleh suatu unit } \\
\text { organisasi atau pemegang jabatan } \\
\text { dalam jangka waktu tertentu. }\end{array}$ & $\begin{array}{l}\text { 2. Waktu produktif, Waktu tidak } \\
\text { produktif, Waktu pribadi }\end{array}$ & $\begin{array}{l}\text { Adisasmito } \\
\text { (2006); }\end{array}$ \\
& & $\begin{array}{l}\text { 3. Absensi } \\
\text { 4. Waktu efektif }\end{array}$ & Ernawati, et \\
& & 1. Waktu kerja & all. (2011); \\
Kebutuhan & Jumlah tenaga yang dibutuhkan & Proborini \\
pegawai & berdasarkan hasil perhitungan dengan & 2. Waktu penyelesaian tugas & (2011); Novera \\
& $\begin{array}{l}\text { pendekatan per tugas jabatan sesuai } \\
\text { Kep. MenPan Nomor: }\end{array}$ & 3. Jumlah kebutuhan pegawai & (2010); \\
& KEP/75/M.PAN/7/2004 & & Setyawan \\
& & & (2008) \\
\hline
\end{tabular}

Langkah pertama pengolahan data yaitu melakukan pemeriksaan terhadap data yang telah diperoleh pada lembar pengamatan work sampling. Kegiatan dikelompokkan berdasarkan kategori kegiatan produktif, tidak produktif dan pribadi. Langkah kedua memasukkan data mengenai standar kemampuan rata-rata waktu penyelesaian tugas-tugas pokok pekerjaan serta kuantitas beban tugas selama setahun. Perhitungan dilakukan menggunakan bantuan Microsoft Excel.

Melalui pengelompokkan kegiatan-kegiatan selama pengamatan, dapat diketahui gambaran penggunaan waktu kerja. Berdasarkan standar kemampuan rata-rata pencapaian waktu untuk menyelesaikan tugas-tugas pokok serta kuantitas beban tugas dalam setahun dapat diketahui. Beban kerja yang diperoleh menjadi dasar untuk melakukan perhitungan jumlah pegawai. Metode perhitungan kebutuhan tenaga kerja yang digunakan sesuai dengan Kep. MenPAN No.

KEP/75/M.PAN/7/2004 tentang Pedoman Perhitungan Kebutuhan Pegawai berdasarkan Beban Kerja dalam rangka Penyusunan Formasi PNS.:

a. Menetapkan waktu kerja

Waktu kerja yang dimaksud adalah waktu kerja efektif. Waktu kerja efektif terdiri atas hari kerja efektif dan jam kerja efektif. Allowance diperkirakan ratarata sekitar 30 persen dari jumlah jam kerja formal.

Hari Kerja Efektif $=(A-(B+C+D))$

Keterangan :

$A=$ Jumlah hari menurut kalender

$B=$ Jumlah hari Sabtu-Minggu setahun

$C=$ Jumlah hari libur dalam setahun

$\mathrm{D}=$ Jumlah cuti tahunan

b. Menyusun Waktu Penyelesaian Tugas (WPT)

Waktu Penyelesaian Tugas (WPT) merupakan hasil perkalian dari jumlah Beban Tugas (BT) pokok dengan waktu Standar Kemampuan Rata-rata (SKR). Rumus perhitungan waktu penyelesaian tugas dapat dilihat pada Tabel 3. 
Tabel 3. Rumus Perhitungan Waktu Penyelesaian Tugas.

\begin{tabular}{ccccc}
\hline No. & Uraian Tugas Pokok & BT & SKR & WPT (BT x SKR) \\
\hline 1 & & & & \\
2 & & & & \\
3 & & & & \\
4 & & & \\
5 & & & \\
dst. & & & \\
\hline$\sum$ WPT &
\end{tabular}

Keterangan :

$\mathrm{BT}=$ Jumlah beban tugas

SKR = Waktu kemampuan rata-rata

WPT $=$ Waktu penyelesaian tugas

Perkalian antara beban tugas dengan waktu standar kemampuan rata-rata dilakukan per tugas pokok. Hasil perkalian dari seluruh tugas pokok dijumlahkan sehingga menghasilkan total Waktu Penyelesaian Tugas.

c. Menghitung Jumlah Pegawai Jumlah kebutuhan pegawai dengan demikian dapat dihitung setelah waktu penyelesaian tugas ditentukan.

Kebutuhan Pegawai $=\frac{\sum \text { Waktu Penyelesaian Tugas }}{\sum \text { Waktu Kerja Efektif }} \times 1$ orang

\section{HASIL DAN PEMBAHASAN}

Berdasarkan hasil observasi, SDM UPBJJ-UT Ternate bekerja lima hari dalam seminggu dari hari Senin hingga Jumat atau sebanyak 238 hari kerja dalam setahun. Adapun jam kerja karyawan pada hari Senin hingga Kamis, yaitu sejak pukul 08.00 WIT sampai dengan pukul 16.30 WIT dan jam kerja karyawan khusus pada hari Jum'at, yaitu sejak pukul 08.30 WIT sampai dengan pukul 17.00 WIT. Hasil pengamatan penggunaan waktu kerja dengan metode work sampling selama dua hari terhadap karyawan administrasi dapat dilihat pada Tabel 4.

Penggunaan waktu untuk kegiatan produktif 45,69-65,39\%. Penggunaan waktu untuk kegiatan tidak produktif 22,45-37,65 \% dan kegiatan pribadi 12,16-14,41\%. Penggunaan waktu kegiatan produktif yang paling tinggi terletak pada unit tata usaha KTU sebesar 65,39 persen atau 667 menit, sedangkan yang paling rendah terdapat pada unit tata usaha ADU sebesar 46,69 persen atau 466 menit. Dari hasil pengamatan, tingginya angka penggunaan waktu untuk kegiatan produktif pada unit KTU dikarenakan aktivitas sehari-hari berhubungan dengan fungsi administratif kepegawaian, administrasi perkantoran, persuratan, dan perencanaan berbagai program kegiatan, serta pelayanan kemahasiswaan dan alumni yang dapat dikatakan cukup padat. 
Tabel 4. Jumlah Penggunaan Waktu Kerja SDM Administrasi UPBJJ-UT Ternate.

\begin{tabular}{|c|c|c|c|c|c|c|c|c|}
\hline \multirow{2}{*}{ Unit } & \multicolumn{3}{|c|}{ Total Waktu (Menit) } & \multirow{2}{*}{ Jumlah } & \multicolumn{3}{|c|}{ Persentase (\%) } & \multirow{2}{*}{$\begin{array}{c}\text { Total } \\
\text { Persentase }\end{array}$} \\
\hline & 1 & 2 & 3 & & 1 & 2 & 3 & \\
\hline KTU & 667 & 229 & 124 & 1020 & 65,39 & 22,45 & 12,16 & 100 \\
\hline$A D U$ & 466 & 384 & 170 & 1020 & 45,69 & 37,65 & 16,67 & 100 \\
\hline$B P P$ & 573 & 309 & 138 & 1020 & 56,18 & 30,29 & 13,53 & 100 \\
\hline$A D K$ & 544 & 329 & 147 & 1020 & 53,33 & 32,25 & 14,41 & 100 \\
\hline TSP & 498 & 380 & 142 & 1020 & 48,82 & 37,25 & 13,92 & 100 \\
\hline$K R U$ & 623 & 258 & 139 & 1020 & 61,08 & 25,29 & 13,63 & 100 \\
\hline$P D A$ & 600 & 261 & 159 & 1020 & 58,82 & 25,59 & 15,59 & 100 \\
\hline Rata-rata & 567,29 & 307,14 & 145,57 & 1020 & 55,62 & 30,11 & 14,27 & 100 \\
\hline Rata-rata per & & & & & & & & \\
\hline hari & 283,64 & 153,57 & 72,79 & 510 & - & - & - & - \\
\hline Jam perhari & 4,73 & 2,56 & 1,21 & 8,50 & - & - & - & - \\
\hline
\end{tabular}

Keterangan :

$1=$ Jenis kegiatan produktif

2 = Jenis kegiatan tidak produktif

$3=$ Jenis kegiatan pribadi

Unit KRU memiliki angka penggunaan waktu produktif sebesar 623 menit atau $61,08 \%$ atau tertinggi kedua setelah unit KTU. Hal ini disebabkan aktifitas pada hari pengamatan juga cukup padat dan beragam. Pekerjaan yang diamati mulai dari pengelompokan (collacting), pemisahan (batching), inputan registrasi, pengelolaan database, ferifikasi, dan validasi data kemahasiswaan.

Urutan tertinggi penggunaan waktu produktif berikutnya unit PDA yaitu sebesar 600 menit atau $58,82 \%$. Angka penggunaan waktu produktif PDA dipengaruhi oleh tugas-tugas administrasi akademik dan kemahasiswaan di lingkup registrasi dan pengujian yang cukup banyak dan beragam, proses pekerjaan dilakukan dengan teliti dengan proses yang panjang. Karyawan PDA harus menangani berbagai kendala registrasi dan menumpuknya inputan data mahasiswa dipenghujung masa registrasi.

Berdasarkan hasil pengamatan di unit BPP, dapat diketahui intensitas pekerjaan yang cukup padat walau tidak sepadat unit KTU, KRU, dan PDA. Dari pengamatan, BPP harus melakukan pengelolaan keuangan pada pelaksanaan kegiatan setiap usulan ketua pelaksana kegiatan serta memastikan administrasi keuangan lengkap dan sesuai dengan ketentuan peraturan keuangan. Waktu produktif BPP yaitu sebesar 573 menit atau sebesar $56,18 \%$.

Hasil pengamatan baik di unit tata usaha TSP (Teknisi Sarana dan Prasarana) dan unit tata usaha ADK (Pengadministrasian Keuangan), dapat diketahui bahwa selama pengamatan berlangsung karyawan TSP dan ADK memiliki penggunaan waktu produktif terendah ke dua dan ketiga setelah Unit tata usaha ADU (Pengadministrasian Umum) yang merupakan unit dalam penggunaan waktu produktif terendah pertama. TSP dan ADK memiliki urutan masing-masing kedua dan ketiga terendah dalam penggunaan waktu produktif yaitu masing-masing dengan angka penggunaan waktu sebesar 498 dan 544 menit atau $48,82 \%$ dan $53,33 \%$. 


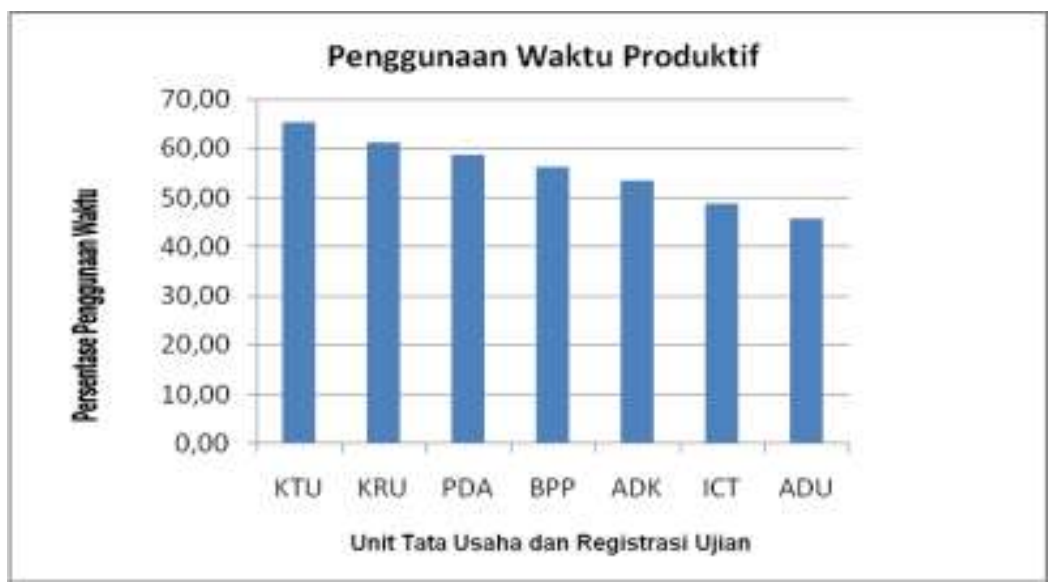

Gambar 1. Diagram batang penggunaan waktu kerja

Dapat diketahui bahwa rata-rata persentase penggunaan waktu untuk jenis kegiatan produktif yaitu sebesar 55,62 persen jauh diatas penggunaan nilai persentase untuk kegiatan tidak produktif yaitu 30,11 persen dan penggunaan nilai persentase untuk kegiatan pribadi yaitu 14,27 persen. Waktu produktif optimal adalah mencapai 55,62 persen. Berdasarkan hal ini, dapat disimpulkan bahwa rata-rata karyawan unit tata usaha dan unit registrasi dan pengujian menggunakan sebesar 34,82 persen dari 43,63 persen waktu produktif mereka untuk mengerjakan kegiatan yang tidak produktif. Nilai ini hampir sama dengan nilai penggunan waktu tidak produktif dan waktu pribadi karywan dengan akumulasi nilai penggunaan waktu sebesar 44,38 persen dari 55,62 persen waktu produktif mereka. Hal tersebut menyebabkan penggunaan waktu kerja untuk kegiatan yang produktif jauh lebih baik.

Karyawan menggunakan waktu sebesar 14,27 persen atau sebesar 145,57 menit untuk kegiatan pribadi. Jika dirata-ratakan per hari, maka karyawan rata-rata menghabiskan sebanyak 72,79 menit atau 1,21 jam untuk kegiatan pribadi untuk keperluan pribadi seperti makan siang, ibadah, istirahat, dan sebagainya.

Analisis mengenai jumlah kebutuhan karyawan untuk pekerjaan administrasi akademik dan kemahasiswaan dilakukan dengan menggunakan metode perhitungan kebutuhan tenaga kerja berdasarkan beban kerja dengan pendekatan tugas per tugas jabatan sesuai Keputusan MenPAN Nomor : KEP/75/M.PAN/7/2004 yaitu :

A. Menetapkan waktu kerja

Hari kerja efektif dapat dihitung dengan jumlah hari berdasarkan kalender 2015 adalah sebanyak 365 hari. Jumlah hari sabtu dan minggu adalah sebanyak 104 hari dalam setahun. Kemudian hari libur nasional pada tahun 2015 adalah sejumlah 11 hari dan cuti tahunan sejumlah 12 hari cuti bersama. Total hari libur diperoleh dengan menjumlahkan hari Sabtu dan Minggu, dengan hari libur nasional dan 12 hari cuti tahunan yaitu sebesar 127 hari. Hari kerja efektif diperoleh dengan mengurangi jumlah hari pada kalender 2015 dengan total hari libur sehingga diperoleh hari kerja efektif yaitu sebanyak 238 hari.

Karyawan UPBJJ-UT Ternate bekerja selama 8,5 jam per hari atau sebanyak 2550 menit per minggu (8,5 jam dikalikan dengan lima hari kerja). Jam kerja efektif adalah jumlah jam kerja formal dikurangi dengan waktu kerja yang hilang karena tidak bekerja (allowance) seperti buang air, melepas lelah, istirahat makan, dan sebagainya. Allowance diperkirakan rata-rata sekitar $30 \%$ dari 
jumlah jam kerja. Dengan demikian, jam kerja efektif karyawan UPBJJ-UT Ternate setelah dikurangi allowance menjadi 1.785 menit per minggu atau 92.820 menit per tahun.

B. Menyusun Waktu Penyelesaian Tugas

Setiap tugas pokok memiliki beban tugas yang menggambarkan seberapa banyak tugas tersebut dilakukan dalam satuan hasil dan jangka waktu tertentu. Misalnya pada unit Pengumpul dan Pengelola Data Akademik (PDA) (lampiran) untuk tugas pelayanan akademik mahasiswa salah satunya adalah Menginput data akademik dan dan kemahasiswaan sesuai format pengolahan data. Beban tugas Menginput data akademik dan dan kemahasiswaan sesuai format pengolahan data selama setahun adalah 2.000 data. Standar kemampuan rata-rata yaitu dalam hal ini 5 menit per data. Waktu Penyelesaian Tugas (WPT) yaitu 2.000 data $\times 5$ menit per data sama dengan 10.000 menit per tahun dan seterusnya.

Hasil pengukuran waktu penyelesaian tugas dapat dilihat misalnya pada unit PDA. Hasil perkalian antara beban tugas dan standar kemampuan rata-rata untuk setiap tugas pokok kemudian dijumlahkan seperti yang terlihat pada lampiran, sehingga total waktu penyelesaian tugas ( $\Sigma$ WPT) adalah 233.320 menit per tahun.

C. Menghitung Jumlah Kebutuhan Pegawai

Misalnya diketahui pada langkah $b$, total waktu penyelesaian tugas administrasi dan akademik pada unit registrasi dan pengujian PDA adalah 233.320 menit per tahun. Jam kerja efektif adalah 92.820 menit per tahun. Jumlah kebutuhan karyawan administrasi akademik dan kemahasiswaan pada unit registrasi dan ujian PDA dapat dihitung dengan membagi jumlah total waktu penyelesaian tugas dengan jam kerja efektif. Hasil pembagian kemudian dikalikan dengan satu orang sehingga diperoleh angka kebutuhan karyawan yaitu sebesar 2,51 orang dan dibulatkan ke atas menjadi 3 orang.

Tabel 5. Ringkasan Perhitungan Jumlah Kebutuhan Karyawan Administrasi UPBJJUT Ternate.

\begin{tabular}{ccc}
\hline Unit & Perhitungan Kebutuhan Karyawan (orang) & Pembulatan (orang) \\
\hline KTU & 1,69 & 2 \\
ADU & 0,51 & 1 \\
BPP & 1,91 & 2 \\
ADK & 1,25 & 1 \\
TSP & 1,49 & 2 \\
KRU & 1,28 & 1 \\
PDA & 2,51 & 3 \\
\hline
\end{tabular}

Jumlah kebutuhan karyawan administrasi pada masing-masing unit tata usaha dan unit registrasi dan pengujian berkisar antara 0,51 hingga 2,51 orang. Perbedaaan angka kebutuhan karyawan dapat menunjukkan bagaimana gambaran beban kerja pada masing-masing unit. Dapat disimpulkan bahwa analisis kebutuhan sumberdaya manusia dengan pendekatan tugas per tugas jabatan memberikan gambaran mengenai jumlah karyawan administrasi yang dibutuhkan pada setiap unit. Adapun jumlah karyawan yang saat ini terdapat pada unit tata usaha dan unit registrasi dan pengujian serta jumlah karyawan yang dibutuhkan dapat dilihat pada Tabel 6 . 
Tabel 6. Perbandingan Jumlah Kebutuhan Karyawan dengan Jumlah Aktual Karyawan.

\begin{tabular}{ccc}
\hline Unit & $\begin{array}{c}\text { Jumlah Kebutuhan Karyawan } \\
\text { (orang) }\end{array}$ & $\begin{array}{c}\text { Jumlah Aktual Karyawan (orang) } \\
\text { KTU }\end{array} 2^{\text {ADU }}$ \\
BPP & 1 & 3 \\
ADK & 2 & 1 \\
TSP & 1 & 1 \\
KRU & 2 & 1 \\
PDA & 1 & 2 \\
\hline
\end{tabular}

Berdasarkan hasil perbandingan jumlah karyawan yang dibutuhkan terhadap jumlah riil atau aktual karyawan, dapat diketahui bahwa terdapat 7 fungsi karyawan, unit tata usaha KTU memiliki kelebihan jumlah karyawan sebanyak 1 orang karyawan dan BPP memiliki kekurangan jumlah karyawan sebanyak 1 orang karyawan. Untuk unit registrasi dan pengujian PDA memiliki kekurangan jumlah karyawan sebanyak 1 orang karyawan. Perhitungan kebutuhan karyawan berdasarkan beban kerja karyawan administrasi akademik dan kemahasiswaan pada unit tata usaha merupakan dasar bagi perencanaan sumberdaya manusia pada UPBJJ-UT Terbuka. Perencanaan SDM merupakan langkah awal dalam menyiapkan SDM yang berkompeten sesuai bidangnya sehingga efisiensi dan efektifitas kerja dapat terwujud dan tujuan perusahaan dapat tercapai (Mangkuprawira, 2003).

Kelebihan jumlah tenaga kerja dapat diatasi dengan cara memperluas pekerjaan dan memperkaya pekerjaan. Perluasan pekerjaan berarti memberikan tambahan aktivitas dengan level yang sama kepada pekerja sehingga meningkatkan jumlah aktivitas yang mereka. Memperkaya pekerjaan berarti merencanakan kembali pekerjaan dengan cara meningkatkan kesempatan pekerja untuk mengalami perasaan tanggung jawab, pencapaian, pertumbuhan dan pengakuan. Langkah lainnya, dapat dilakukan dengan pemindahan tenaga kerja pada unit yang kelebihan tenaga kerja ke unit yang mengalami kekurangan tenaga kerja dengan terlebih dahulu melihat kompetensi tenaga kerja yang bersangkutan.

Tugas-tugas pokok administrasi kemahasiswaan pada unit memiliki tugas pokok pekerjaan yang berbeda-beda sesuai dengan bidang kerja yang ditangani. Semua tugas sudah tertera dalam pedoman pekerjaan yang telah disusun dan harus dipertanggunjawabkan pada Capaian Sasaran Kinerja Pegawai (CSKP). Berdasarkan hasil pengamatan diketahui bahwa pegawai pada unit-unit administrasi operasional akademik UPBJJ-UT Ternate bekerja lima (5) hari dalam seminggu, yaitu dari hari Senin hingga Jumat. Bila di rata-rata sebanyak 20 hari kerja dalam sebulan atau sebanyak 238 hari kerja dalam setahun. Adapun jam kerja karyawan per hari yaitu sejak pukul 08.00 sampai dengan pukul 16.30 WIT.

Berdasarkan rata-rata persentase penggunaan waktu oleh pegawai administrasi secara keseluruhan unit untuk setiap jenis kegiatan, dapat disimpulkan bahwa rata-rata persentase penggunaan waktu untuk jenis kegiatan produktif yaitu sebesar 55,62 persen (waktu produktif optimal) jauh diatas penggunaan nilai persentase untuk kegiatan tidak produktif yaitu 30,11 persen dan penggunaan nilai persentase untuk kegiatan pribadi yaitu 14,27 persen. Berdasarkan hal ini, dapat disimpulkan bahwa rata-rata pegawai administrasi menggunakan sebesar 64,67 persen dari 81,04 persen waktu produktif mereka untuk mengerjakan kegiatan yang tidak produktif. Selisih sebesar 16,37 persen. Nilai ini hampir sama dengan nilai penggunan waktu tidak produktif dan waktu 
pribadi karyawan dengan akumulasi nilai penggunaan waktu sebesar 44,38 persen dari 55,62 persen waktu produktif mereka. Selisih sebesar 11,24 persen. Hal tersebut menyebabkan penggunaan waktu kerja untuk kegiatan yang produktif jauh lebih baik. Sedangkan untuk jenis kegiatan pribadi, rata-rata karyawan menghabiskan sebanyak 72,79 menit atau 1,21 jam per hari untuk kegiatan pribadi. Hal ini masih sesuai dengan jam untuk keperluan pribadi seperti makan, ibadah, istirahat, dan sebagainya, yang ditetapkan bagi karyawan yang bekerja di UPBJJ-UT Ternate yaitu satu jam.

\section{REFERENSI}

Ernawati, Ni Luh Ade Kusuma. (2011). Kebutuhan riil tenaga perawat dengan metode Workload Indicator Staff Need (WISN). Jurnal Ners, vol. 6(1), pp.86-93.

Ilyas, Y. (2004). Perencanaan SDM Rumah Sakit: Teori, metode dan formula. fakultas kesehatan mayarakat. Depok: Universitas Indonesia.

Keputusan Menteri Pendayagunaan Aparatur Negara Nomor : KEP/75/M.PAN/7/2004 tentang Pedoman Perhitungan Kebutuhan Pegawai Berdasarkan Beban Kerja dalam rangka Penyusunan Formasi Pegawai Negeri Sipil.

Mangkuprawira, S. (2003). Manajemen sumber daya manusia strategik. Jakarta: PT. Ghalia Indonesia.

Moekijat. (2008). Analisis jabatan. Bandung: CV. Mandar Maju.

Novera, Windry. (2010). Analisis Beban Kerja dan Kebutuhan Karyawan Bagian Administrasi Akademik dan Kemahasiswaan (Studi Kasus Unit Tata Usaha Departemen Pada Institut Pertanian Bogor). URL: http://repository.ipb.ac.id/handle/123456789/47740. 08 Februari 2015.

Proborini, Niken. (2011). Analisis beban kerja dan kebutuhan pegawai pada Perusahaan Daerah Air Minum (PDAM) Tirta Kahuripan Kabupaten Bogor Cabang Sebelas.URL: http://repository.ipb.ac.id/handle/123456789/54326. 17 Maret 2015.

Setyawan, Teguh. (2008). Analisis Beban Kerja dan Kebutuhan Sumber Daya Manusia (Studi Kasus Seksi MDF Bogor Centrum Kantor Daerah Telkom Bogor).URL: http://repository.ipb.ac.id/handle/123456789/18444. 17 Maret 2015.

Suharyono, M. Waseso dan Adisasmito, Wiku B.B. (2006). "Analisis Jumlah Kebutuhan Tenaga Pekarya dengan Work Sampling Di Unit Layanan Gizi Pelayanan Kesehatan”. Jurnal Manajemen Pelayanan Kesehatan. Vol. 6 Nomor 02. pp.72-79. 